\title{
The trace element signature of Ecuadorian magma: slab or crustal origin
}

\author{
DIEGO F. F. NARVÁEZ ${ }^{1,2}$, PABLO SAMANIEGO ${ }^{3}$, \\ KENNETH T. KOGA ${ }^{4}$, ESTELLE F. ROSE-KOGA ${ }^{5}$, \\ SILVANA HIDALGO ${ }^{6}$ AND GUEORGUI RATZOV ${ }^{7}$ \\ ${ }^{1}$ Laboratoire Magmas et Volcans \\ ${ }^{2}$ Departamento de Geología, Escuela Politécnica Nacional \\ ${ }^{3}$ Laboratoire Magmas et Volcans, Université Clermont Auvergne \\ ${ }^{4}$ Université Clermont Auvergne \\ ${ }^{5}$ Laboratoire Magmas et Volcans - CNRS \\ ${ }^{6}$ Instituto Geofísico, Escuela Politécnica Nacional \\ ${ }^{7}$ Université Côte d'Azur, IRD, CNRS, Observatoire de la Côte \\ d'Azur, Géoazur \\ Presenting Author: diego.fe.rn@hotmail.com
}

Tracing the source of geochemical indexes to subduction zone processes is an important exercise in providing constraints of arc magma genesis. The origin of some geochemical indexes, such as high $\mathrm{La} / \mathrm{Yb}, \mathrm{Ba} / \mathrm{Th}$ in continental arc lavas is controversial and inconclusive as to whether they are imparted by the slab or acquired in the crust. In Ecuador, where volcanoes are built over a thick crust $(\sim 50 \mathrm{~km})$, this problem is grounded in the lack of erupted primitive rocks. Therefore, many previous studies focused on whole-rock samples of intermediate to silica-rich magmas, and found dominant overprinting of the crustal process. Here, we used melt inclusions hosted in $\mathrm{Fo}_{80-90}$ olivines to decipher the slab component in magma, as such samples were expected to have less crustal interaction than whole rocks. Our data show that the slab component is the main contributor leading to the trace elements geochemical variability of Ecuadorian primitive magmas. We analyzed major, trace and volatile elements in experimentally-heated melt inclusions from high-Mg rocks. These MIs display ultrabasic to basic compositions (42.0-51.8 wt.\%. $\mathrm{SiO}_{2}$ ) and fall in the field of basalts, trackybasalts and basanites in the TAS diagram. On the basis of trace elements and geochemical modelling, we recognize two types of slab components: the first is indicative of aqueous fluids (e.g., high $\mathrm{Ba} / \mathrm{La}, \mathrm{Pb} / \mathrm{Ce}, \mathrm{B} / \mathrm{Nb}$ ), and the second of hydrous siliceous melts (e.g., high $\mathrm{La} / \mathrm{Nb}, \mathrm{Th} / \mathrm{Nb}$ ). Together, these slab components can account for the whole trace elements geochemical variations of Ecuadorian volcanic rocks ruling out the need for the crust involvement (i.e. crustal assimilation) in magma compositions. The hydrous siliceous melt is recognized in Northern Ecuador where a young oceanic crust $(<20 \mathrm{Ma})$ enters in subduction. Also, this geochemical signature is only observed in volcanoes located $>120 \mathrm{~km}$ above the subducted slab. Our geochemical model identifies the components of the subducted oceanic crust and its overlying continental-derived sediments. Also, the geochemical modelling failed to reproduce the composition of melt inclusions by crustal processes such as: assimilation, fractional crystallization or mixing. These results strengthen the conclusion that the magma genesis Ecuador is strongly influenced by diverse contributions from slab. 